\section{Transformation of a Strawberry Cultivar Using a Modified Regeneration Medium}

\author{
Vellicce Gabriel Ricardo, Yamilet Coll, Atilio Castagnaro, and \\ Juan Carlos Diaz Ricci \\ Instituto de Química Biológica “Dr Bernabé Bloj," Facultad de Bioquímica, \\ Química y Farmacia; Instituto Superior de Investigaciones Biológicas, \\ Departamento de Bioquímica de la Nutrición, Universidad Nacional de \\ Tucumán, Chacabuco 461, C.P. 4000 - Tucumán, Argentina
}

Additional index words. Agrobacterium, B-glucuronidase, Fragaria $\times$ ananassa, genetic transformation

\begin{abstract}
A protocol for shoot regeneration of strawberry (Fragaria xananassa Duch. 'Pajaro') leaf disks was developed. In Murashige and Skoog basal medium with $3 \%$ of sucrose $(w / v), B A\left(1 \mathrm{mg} \cdot \mathrm{L}^{-1}\right)$, and $2,4-D\left(0.1 \mathrm{mg} \cdot \mathrm{L}^{-1}\right), 70 \%$ of the cultivated leaf explants regenerated plants. This regeneration system was used for genetic transformation of strawberry with Agrobacterium tumefaciens strain LBA 4404 carrying the binary vector plasmid pBI121 that contains the npt II (neomycin phosphotransferase) and uidA (B-D glucuronidase) genes. A transformation rate of 6.6\%, calculated as the number of leaf disks able to regenerate kanamycin-resistant plants/total leaf disks infected, was obtained. The integration of both marker genes was evaluated in each transformed line by PCR (polymerase chain reaction) amplification of the $n p t$ II and uidA genes. High expression levels of the uidA gene were found in leaves, flower, and fruits of the transgenic lines. The protocol here reported may represent a way to conduct transformation research in strawberries. Chemical names used: benzyladenine (BA); 2,4-dichlorophenoxyacetic acid (2,4-D).
\end{abstract}

The development of an efficient and reliable transformation procedure is the first step in the genetic manipulation of cultivated plant species at the molecular level. The availability of micropropagation and regeneration systems coupled with the susceptibility to infection by Agrobacterium sp. (Uratsu et al., 1991) makes the strawberry well suited for genetic transformation studies. The clonal propagation of strawberry provides an added advantage for stable transfer of genes associated with desirable agronomic traits to commercially important genotypes.

In the past decade various experimental methods have been devised to accomplish the transformation of cultivated strawberries and the wild strawberry Fragaria vesca L. (Barceló-Muñoz et al., 1998; El-Maunsouri et al., 1996; Graham et al., 1990; James et al., 1990; Jelenkovic et al., 1986; Mathews et al., 1995; Nehra et al., 1990a, 1990b; Nyman et al., 1992). However, transformation success is highly dependent on the particular strawberry genotype used, and a protocol developed for one cultivar is not necessarily applicable to others.

Fragaria $\times a n a n a s s a$ cv. Pajaro is an excellent strawberry cultivar. From 1980 to 1990 it was one of the most commercially important cultivars in Argentina, but planting acreage has decreased due to susceptibility to a local strain of Colletotrichum acutatum (Ramallo et al., 2000). Nevertheless, this cultivar is still be-

Received for publication 9 Apr. 2002. Accepted for publication 22 Aug. 2002. ing used as important parental line in breeding programs (Craig Chandler, pers. comm.).

In this report, we describe the development of a high frequency Agrobacteriummediated genetic transformation protocol for the introduction of two marker genes into the cultivar Pajaro of strawberry using a leaf disk regeneration system. We were successful to accomplish the genetic transformation with a protocol that provides strawberry researchers the chance to conduct transformation research without infringing the U.S. patents $6,274,791$ and $5,750,870$. The first protects a method for strawberry transformation mediated by $A$. tumefaciens using glucose or fructose in the regeneration medium and the second patent protects an iterative procedure for recovery of uniformly transformed plants. The protocol described here uses sucrose in the regeneration medium and a one-step-selection-procedure in rooting medium with kanamycin to recover uniformly transformed plants. The transgenic plants obtained with our protocol showed high expression levels of the uidA reporter gene.

\section{Materials and Methods}

Plant material and culture conditions. In vitro stock plants of 'Pajaro' proliferating in multiplication medium with $2.21 \mu \mathrm{M}$ of kinetin (6-furfurylaminopurine) were used. Leaf disks of $4 \times 4 \mathrm{~mm}$ with the adaxial surface in contact with the medium were used as explants. The basal medium contained: $3 \%(\mathrm{w} / \mathrm{v})$ of sucrose and $0.22 \%(\mathrm{w} / \mathrm{v})$ of Phytagel (Sigma, St. Louis), vitamins and mineral salts according to Murashige and Skoog (1962). The $\mathrm{pH}$ of all media was adjusted to 5.7 with sodium hydroxide $0.1 \mathrm{~N}$ and autoclaved for $20 \mathrm{~min}$ at $121{ }^{\circ} \mathrm{C}$. Culture conditions were $25 \pm 2{ }^{\circ} \mathrm{C}$ temperature and a $16-\mathrm{h}$ photoperiod under 40 $\mu \mathrm{mol} \cdot \mathrm{m}^{-2} \cdot \mathrm{s}^{-1}$ irradiance.

The effect of growth regulator balance on the morphogenetic response was studied. The growth regulators BA and 2,4-D were used in combination of $0,1,2,3,4 \mathrm{mg} \cdot \mathrm{L}^{-1}$ and $0,0.1$, $0.2,0.3 \mathrm{mg} \cdot \mathrm{L}^{-1}$, respectively. In regeneration experiments, the number of regenerating disks was evaluated after 8 and 16 weeks of culture.

Bacterial strain and plasmids. Agrobacterium tumefaciens strain LBA 4404 containing the non-oncogenic plasmid pAL 4404 and the binary vector pBI121 (Jefferson et al., 1987) was used in transformation experiments. The pBI121 plasmid, containing the phosphotransferase gene (npt II) for kanamycin resistance and $\beta$-glucuronidase gene (uidA) as a reporter gene, was introduced into Agrobacterium by the "freeze-thaw" transformation method (Holsters et al., 1978).

Transformation procedure and characterization of transformants. Transformation experiments started by pre-culturing, prior to Agrobacterium infection, 60 leaf disks for $4 \mathrm{~d}$ in antibiotic free regeneration medium. Three identical and independent transformation experiments were performed. Incubation was carried out in petri dishes containing 25 $\mathrm{mL}$ of regeneration medium (Basal medium supplemented with $1 \mathrm{mg} \cdot \mathrm{L}^{-1}$ of BA and 0.1 $\mathrm{mg} \cdot \mathrm{L}^{-1}$ of $\left.2,4-\mathrm{D}\right)$. After this induction period explants were inoculated with an overnight culture of Agrobacterium, grown at $28^{\circ} \mathrm{C}$ in Luria Broth base (LB) medium containing 50 $\mathrm{mg} \cdot \mathrm{L}^{-1}$ kanamycin, diluted in MS medium at $\mathrm{OD}_{600}=2.0$ and gently shaken for $15 \mathrm{~min}$. Infected explants were blot-dried on sterile filter paper and co-cultivated in the dark for $2 \mathrm{~d}$ at $25^{\circ} \mathrm{C}$. The leaf disks were then transferred to a regeneration medium supplemented with $25 \mathrm{mg} \cdot \mathrm{L}^{-1}$ of kanamycin and $500 \mathrm{mg} \cdot \mathrm{L}^{-1}$ of cefotaxime (selection medium) under the culture conditions mentioned above and transferred intact to fresh medium every 30 d. Cefotaxime was used to inhibit growth of A. tumefaciens.

The shoots that regenerated on selection medium were transferred after 18 weeks to a rooting medium (MS free of growth regulators supplemented with $25 \mathrm{mg} \cdot \mathrm{L}^{-1}$ of kanamycin). The shoots were scored for root formation after 4 weeks of culture.

The GUS [ $\beta$-glucuronidase (EC 3.2.1.31)] activity was determined in leaves, roots, fruits and flowers of transformed lines by histochemical and fluorimetric assays according to Jefferson et al. (1987). The histochemical detection used X-Gluc (4-chloro-3-indolyl-3-D-glucuronide) as substrate prepared essentially as described by Stomp (1992). Histochemical reaction was performed by incubating plant tissues in $200 \mu \mathrm{L}$ of X-Gluc solution at $37{ }^{\circ} \mathrm{C}$ until the development of the blue color (2-12 h). For fluorimetric assays, $20 \mathrm{mg}$ of young fully expanded leaves, petals and fruit organs were homogenized separately in the following extraction buffer: $50 \mathrm{~mm} \mathrm{NaHPO}_{4} \mathrm{pH} 7 ; 10 \mathrm{~mm}$ 2-mercaptoethanol; $10 \mathrm{~mm} \mathrm{Na}$ EDTA; $0.1 \%$ 
sodium lauryl sarcosine; $0.1 \%$ triton $\mathrm{X}-100$. The homogenate obtained was then centrifuged $(5000 \mathrm{~g})$ at $4{ }^{\circ} \mathrm{C}$ for $10 \mathrm{~min}$ and the supernatant collected; $5-10 \mu \mathrm{L}$ of extract was incubated at $37{ }^{\circ} \mathrm{C}$ for $0,5,10$, and $15 \mathrm{~min}$ with $2 \mathrm{~mm}$ of MUG(4-methylumbelliferyl B-D-glucuronide) dissolved in extraction buffer. The time course assay (in triplicate) was performed from two independent extractions of each transformed plant. At the end of the incubation time, the reaction was stopped by adding $2 \mathrm{~mL}$ of sodium carbonate $200 \mathrm{~mm}$ and the fluorescence register in a DyNA Quant 200 fluorometer (Hoefer Pharmacia Biotech, San Francisco). Total soluble protein was determined by using the BIO-RAD Protein Assay (BIO-RAD Laboratories, Hercules, Calif.).

DNA isolated from leaves of transformed and control plants using the methods of Mercado et al. (1999) was tested for the presence of the $n p t I I$ and uid A marker genes by PCR (polymerase chain reaction) according to Haymes and Davis (1998). Additionally the presence of Agrobacterium contamination in transformed plants was tested by PCR amplification of a fragment of the gene virD1 contained in the $\mathrm{Ti}$ plasmid (Lip-Joao and Brown, 1993). Primers used were $\left(5^{\prime}-3^{\prime}\right)$ : TCCAGATCATCCTGATCGACAAG (forward) and CAAGATGGATTCCACGCAGGTTC (reverse) for the nptII gene; CAACGCTGACATCAC (forward) and ACTGGCAGACTATCC (reverse) for the uidA gene; ATGTCGCAAGGCAGTAAGCCCA (forward) and GGAGTCTTTCAGCATGGAGCAA (reverse) for virD1 gene. Expected sizes of the $n p t \mathrm{II}$, uidA, and $v i r \mathrm{D} 1$ amplification products are 503, 230, and 437 $\mathrm{bp}$, respectively.

The PCR reaction volume was $20 \mu \mathrm{L}$, containing: 0.5 units of Taq polymerase (Promega, Madison, Wis.), $1 \times$ Taq buffer, $1.5 \mathrm{mM} \mathrm{MgCl}_{2}$, $0.1 \mathrm{~mm}$ each dNTP, $0.4 \mu \mathrm{M}$ of the corresponding $n p t I I$, uidA, or vir D1 primers and $50 \mathrm{ng}$ of the plant DNA. In control experiments 10 ng of the plasmid (pBI121) or Agrobacterium tumefaciens DNA used. An PTC-100 thermocycler (MJ-Research, Watertown, Mass.) was used for the PCR reactions using the following step cycle program: $94{ }^{\circ} \mathrm{C}, 50 \mathrm{~s} ; 60^{\circ} \mathrm{C}, 1 \mathrm{~min}$ and $72{ }^{\circ} \mathrm{C}, 2 \mathrm{~min}$ for 35 cycles linked to a final $72{ }^{\circ} \mathrm{C} 5$ min extension.

In order to evaluate the heredity of foreign genes into the progeny, two independent crosses between a transformed line and a non transformed 'Pajaro' plants were made. The hybrid seeds were aseptically germinated to obtain R1 seedlings and tested for kanamycin resistance and GUS activity. Surface sterilized seeds were transferred to petri dishes containing basal medium added with $50 \mathrm{mg} \cdot \mathrm{L}^{-1}$ of kanamycin and incubated for 6 weeks under conditions mentioned above. Seeds germinated in the first two weeks and kanamycin resistances were scored 4 weeks later. Leaf sections of the newly germinated seedlings were incubated separately in a 96-well microtiter plate with $100 \mu \mathrm{L} \mathrm{X-Gluc} \mathrm{substrate} \mathrm{solution} \mathrm{(Jefferson} \mathrm{et}$ al., 1987) per well. Microtiter plates were then incubated overnight at $37^{\circ} \mathrm{C}$ in the dark. After incubation in the X-Gluc, GUS activity was indicated by the blue color of the tissues.
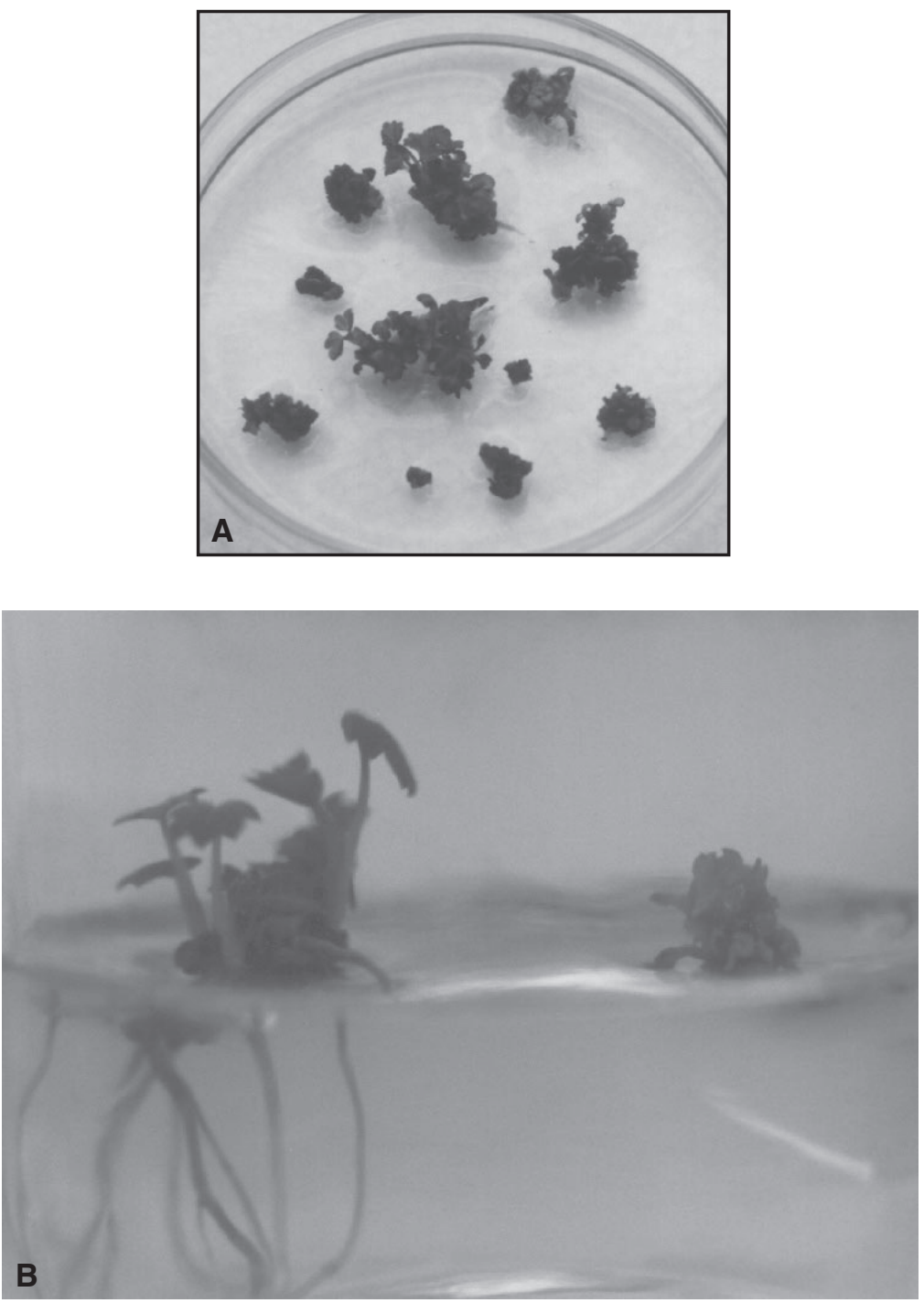

Fig. 1. (A) Regeneration of strawberry plants Fragaria xananassa cv. Pajaro from leaf disks in selection medium; (B) transformed (left) and control shoots (right) in rooting media containing $25 \mathrm{mg} \cdot \mathrm{L}^{-1}$ of kanamycin.

\section{Results and Discussion}

Plant regeneration from leaf disks. Evaluation of the regeneration showed no regeneration when BA or 2,4-D was absent in the media. In other strawberry cultivars, auxins and cytokinins were required to induce the regeneration of plants from leaf disks. Liu and Sanford (1988) observed different requirement of cytokinins and auxin levels to induce regeneration from leaf disks Fragaria xananassa cv. Allstar depending on the source of explants. These authors reported that $2.5 \mathrm{mg} \cdot \mathrm{L}^{-1}$ of BA and 0.5 $\mathrm{mg} \cdot \mathrm{L}^{-1}$ of IBA (indole- 3 butyric acid) induced $79 \%$ of regeneration from leaf disks coming from in vitro culture, while leaves of plants grown in greenhouse regenerated at $34 \%$ with 3 $\mathrm{mg} \cdot \mathrm{L}^{-1}$ of BA and $0.1 \mathrm{mg} \cdot \mathrm{L}^{-1}$ of IBA. Nehra and Stushnoff (1989) found that BA at $2.25 \mathrm{mg} \cdot \mathrm{L}^{-1}$ and IAA (indole- 3 acetic acid) at $1.75 \mathrm{mg} \cdot \mathrm{L}^{-1}$ induced $93 \%$ of regeneration when leaf disks of Fragaria $\times$ ananassa cv. Redcoat grown in greenhouse were used. Barceló et al. (1998) used $1 \mathrm{mg} \cdot \mathrm{L}^{-1}$ and $0.5 \mathrm{mg} \cdot \mathrm{L}^{-1}$ of BA and IBA, respectively, for shoot regeneration from leaf disks of Fragaria $\times$ ananassa cv. Chandler and observed that higher levels of hormone in the media decreased the regeneration efficiency. Our results show a yield of $70 \%$ of shoot regeneration when in vitro disks of Fragaria $\times$ ananassa $\mathrm{cv}$. Pajaro were cultivated with BA and 2,4-D at $1 \mathrm{mg} \cdot \mathrm{L}^{-1}$ and $0.1 \mathrm{mg} \cdot \mathrm{L}^{-1}$, respectively. The leaf disks started to regenerate after 8 weeks and 8 weeks later formed a cluster of 5-10 shoots from each regeneration site. This media was used in later transformations experiments. The higher hormone concentrations used in experiments with Fragaria xananassa $\mathrm{cv}$. Pajaro had negative effects on the regeneration process, $0.2-0.3 \mathrm{mg} \cdot \mathrm{L}^{-1}$ of $2,4-\mathrm{D}$ and $2-4$ $\mathrm{mg} \cdot \mathrm{L}^{-1}$ of BA induced callus formation but no plant regeneration.

Genetic transformation. In three independent experiments, a total of 180 leaf explants were co-cultivated with the Agrobacterium strain LBA4404 carrying the plasmid pBI121 and cultured in the medium for plant regeneration with $25 \mathrm{mg} \cdot \mathrm{L}^{-1}$ of kanamycin. After 8 weeks, four leaf explants from each independent experiment showed kanamycin resistant 

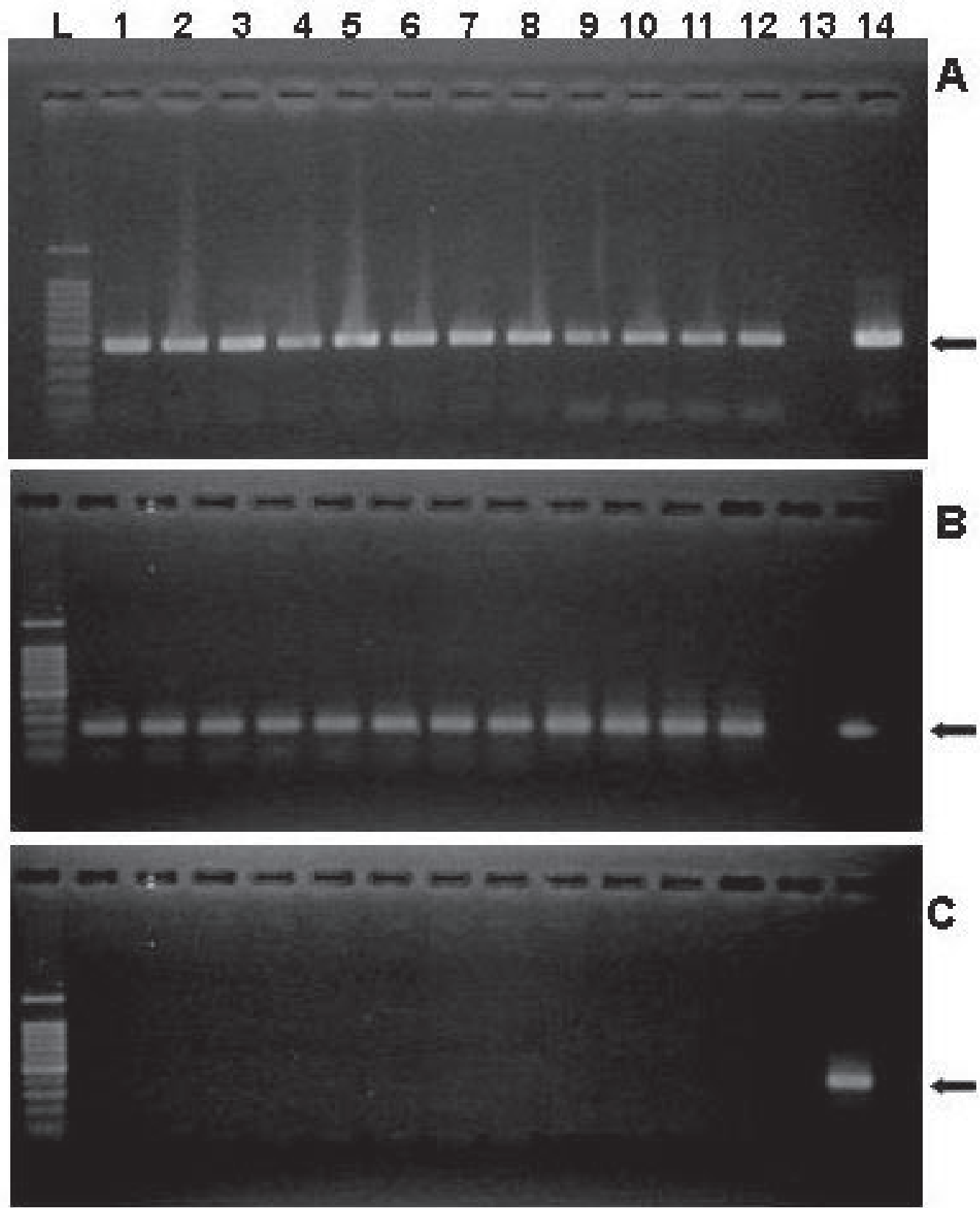

Fig. 2. PCR amplification of the $n p t I I(A)$, uidA (B), and virD1 (C) genes electrophoresed in 1.5\% agarose gel. Arrows indicate the 503-, 230-, and 437-bp fragments, respectively. Lane L: molecular weight marker; 1-12: transformed plants, 13: untransformed control plant; 14: positive controls from pBI121 plasmid in $\mathrm{A}$ and $\mathrm{B}$, and A. tumefaciens DNA in $\mathrm{C}$.

calli and, 18 weeks later, all of those formed a cluster of green healthy shoots (Fig. 1A). These primary transformants were transferred to a rooting medium containing $25 \mathrm{mg} \cdot \mathrm{L}^{-1}$ of kanamycin to select uniformly transformed plants. After 8 weeks of culture the transgenic shoots formed roots in this medium while the controls shoots (not transformed plants) died (Fig. 1B). The fastest growing and most vigorous rooting plants under antibiotic pressure were selected for further analysis. The transformation efficiency calculated as a number of kanamycin resistance events (coming from separate shoot clusters) with respect to a total number of leaf disks infected was $6.6 \%$. The transformation rate reported for the strawberry cultivar Redcoat was 3\% when using calli as explants (Nehra et al., 1990a) and 6.5\% for the same cultivar when using a leaf disk regeneration system (Nehra et al., 1990b). However, these plants were not able to root well in the selection medium containing $25 \mathrm{mg} \cdot \mathrm{L}^{-1}$ of kanamycin. Other protocols reported for the transformation of Fragaria xananassa cvs. Tristar and Totem, yielded efficiency as high as $12.5 \%$ and $58.8 \%$, respectively, but the regenerated plants showed evidence of chimerism, even after an iterative selection procedure in which kanamycin was increased stepwise from 5 to $200 \mathrm{mg} \cdot \mathrm{L}^{-1}$ (Mathews et al., 1998). Barceló et al. (1998) and De Mesa et al. (2000) also reported the transformation of the Fragaria $\times$ ananassa cv. Chandler with an efficiency of $4.22 \%$ and $20.7 \%$, respectively, when plants were regenerated in the presence of $25 \mathrm{mg} \cdot \mathrm{L}^{-1}$ of kanamycin. The former authors used the
Agrobacterium mediated transformation protocol (Barceló et al., 1998), the latter used an Agrobaterium-coated microparticle bombardment procedure (DeMesa et al., 2000).

Analysis of transformants. The elimination of Agrobacterium contamination during the selection process was tested by cultivation of leaf and crown fragments of transgenic plants on antibiotic-free LB medium for 30 days. Results of PCR amplification of the Agrobacterium virD1 gene fragment from DNA of transformed plants were negative confirming the absence of contaminations in transformed plants (Fig. 2). The presence of $n p t I I$ and $u i d \mathrm{~A}$ genes in the DNA of transgenic plants was also evaluated by PCR. The expected $230 \mathrm{bp}$ and 503 bp bands corresponding to the uidA and $n p t I I$ genes, respectively, were found in 
Table 1. B-glucuronidase activity detected by fluorimetric assay of transformed plants of strawberry Fragaria $\times$ ananassa cv. Pajaro.

Lines of

transformed

plants

AF55-1

AF55-2

AF55-3

AF55-4

AF56-1

AF56-2

AF56-3

AF56-4

AF57-1

AF57-2

AF57-3

AF57-4

Untransformed

control

all transformed plants and absent in the untransformed control plants (Fig. 2).

The transformed plants were screened for GUS activity using the histochemical assay in leaf, petiole and roots. In all tissues analyzed, histochemical staining was uniform (data not shown), suggesting the absence of chimeric plants; we observed no kanamycin-resistant plants that did not show GUS activity. GUS expression level was quantified in leaves of runner plants (R0) by fluorimetric assays. The expression level of the GUS attained in our experiments was between 19 and 151.2 nmoles of 4-MU (4-methylumbelliferone) produced/min/mg protein (Table 1) and the values displayed by each line did not show significant variations after one year from the first assay. The GUS expression values reported by Nehra et al (1990a) range between 0.17 and 8.37 nmoles of 4-MU produced/min/mg protein for plants regenerated from calli and between 0.32 and $0.577 \mathrm{nmoles}$ of $4-\mathrm{MU}$ produced $/ \mathrm{min} / \mathrm{mg}$ protein for plants regenerated from leaf disks (Nehra et al., 1990b). DeMesa et al. (2000) also reported lower values of GUS activity in transformed plants of the cultivar Chandler obtained by bombardment procedure.

We have also quantified the GUS activity levels in flowers and ripe fruits of the transgenic lines 55-4, 56-3, and 57-1 and observed that flowers and fruits showed lower activity than leaf tissues (Table 2). The latter confirms that uidA gene is being expressed in different tissue of the plant.

Crosses among untransformed 'Pajaro' plants (mothers) with plants of the transformed line 55-2 were carried out (e.g., backcross) to confirm transmission of the uidA gene. Segregant hybrid achenes (351) were evaluated for kanamycin resistance and GUS activity. Of the 351 achenes tested 333 germinated and formed seedlings, 165 were classified as resistant and 168 as susceptible to kanamycin. Histochenical determination of GUS activity showed that all the kanamycin resistant seedlings were GUS positive and the rest were GUS negative. These results indicate that both genetic markers (kanamycin resistance and GUS activity) segregate together; therefore, the gene $n p t I I$ is co-inherited with the uidA gene. Furthermore,
Table 2. B-glucuronidase activity detected in different plant tissues by fluorimetric assay of transformed lines of strawberry Fragaria $\times$ ananassa cv. Pajaro.

\begin{tabular}{lccc}
\hline \multirow{2}{*}{$\begin{array}{l}\text { Lines of } \\
\text { transformed }\end{array}$} & \multicolumn{3}{c}{$\begin{array}{c}\text { GUS activity } \\
\text { (nmoles of 4-MU produced/ } \\
\text { min/mg protein) }\end{array}$} \\
\cline { 2 - 4 } plants & Leaves & Flowers & Fruits \\
\hline AF55-4 & $150 \pm 2$ & $20 \pm 2$ & $83 \pm 5$ \\
AF56-3 & $151 \pm 4$ & $45 \pm 3$ & $77 \pm 4$ \\
AF57-1 & $60 \pm 7$ & $6 \pm 1$ & $17 \pm 1$ \\
Untransformed & 0 & 0 & 0 \\
control & & & \\
\hline
\end{tabular}

the ratio of plants GUS+/GUS- (e.g., 165/168)

$1: 1$ corresponded to the ratio expected for the segregation of a single dominant gene.

The protocol presented in this paper provides a useful alternative for strawberry transformation that avoids potential conflicts with current effective patents. The U.S. patent 5,750,870 protects an Agrobacterium-mediated method that uses an iterative procedure to optimize the yield of uniformly transformed plants. The procedure consists on subjecting the primary shoot "regenerants" obtained in the first selection medium to several cycles of tissue isolation and culture on progressively higher antibiotic concentration in the medium, thereby the plants undergo rooting in the presence of kanamycin or hygromycin. With our protocol the recovery of uniformly transgenic plants is made by culture of primary transformants directly in a rooting medium containing kanamycin at 25 $\mathrm{mg} \cdot \mathrm{L}^{-1}$ and selecting the fastest growing and most vigorous rooting plants. The U.S. patent $6,274,791$, on the other hand, protects a method for strawberry transformation mediated by $A$. tumefaciens using glucose or fructose in the regeneration medium whereas the regeneration medium described here uses sucrose.

We would like to emphasize that although the strawberry transformation protocol presented here does not infringe intellectual properties for the reasons mentioned above and because our work was carried out in the frame of an academic research, there are few things that have to be considered carefully before any attempt to used it in commercial breeding program. Even though Fragaria xananassa cv. Pajaro is no longer protected with a patent within U.S territory, restriction may still persist outside the United States. In the latter case, permission should be requested to the Univ. of California at Davis. Likewise, the use of some regulatory sequences and other molecular motives used in cloning and expressions of genes in plants may also be protected by patents [e.g., CaMV 35S (cauliflower mosaic virus) promoter is under Monsanto patent U.S. $5,352,605]$ and therefore should be thoroughly considered by commercial line breeders.

\section{Literature Cited}

Barceló-Muñoz, M., I. El-Mansouri, J.A. Mercado, M.A Quesada, and F. Pliego-Alfaro. 1998. Regeneration and transformation via Agrobacterium tumefaciens of the strawberry cultivar Chandler. Plant Cell Tissue and Organ Culture 54:29-36.

DeMesa-Cordero, M., S. Jimenez-Bermudez, F. PliegoAlfaro, M.A. Quesada, and J.A. Mercado. 2000. Agrobacterium cells as microprojectile coating: a novel approach to enhance stable transformation rates in strawberry. Aust. J. Plant Physiol. 27: 1093-1100.

El-Mansouri, I., J.A. Mercado, V. Valpuesta, J.M. LopezAranda, F. Pliego-Alfaro, and M.A. Quesada. 1996. Shoot regeneration and Agrobacterium-mediated transformation of Fragaria vesca $\mathrm{L}$. Plant Cell Rpt. 15:642-646.

Graham J., J.R. McNicol, and A. Kumar. 1990. Agrobacterium-mediated transformation of soft fruit Rubus, Ribes, and Fragaria in Methods in Molecular Biology, Vol 44, Agrobacterium Protocols. K.M.A. Gartland and M.R. Davey (ed). Humana Press, Totowa, N.J.

Haymes, K.M. and T.M. Davis. 1998. Agrobacteriummediated transformation of "Alpine" Fragaria vesca, and transmission of transgenes to $\mathrm{R} 1$ progeny. Plant Cell Rpt. 17:279-283.

Holsters, M., D. de Waele, A. Depicker, E. Messens, M. Van Montagu, and J. Schell. 1978. Transfection and transformation of A. tumefaciens. Mol. Gen. Genet. 163:181-187.

James, D.J., A.J. Passey, and D. Barbara. 1990. Agrobacterium-mediated transformation of the cultivated strawberry (Fragaria $\times$ ananassa Duch.) using a disarmed binary vectors. Plant Sci. 69:79-94.

Jefferson, R.A., T.A. Kavanagh, and M. Bevan. 1987. GUS fusions: B-glucuronidase as a sensitive and versatile gene fusion marker in higher plants The EMBO journals 6:3901-3907.

Jelenkovic, G., C.K. Chin, and S. Billings. 1986. Transformation studies of Fragaria xananassa Duch. by $\mathrm{Ti}$ plasmid of Agrobacterium tumefaciens. HortScience 21:695.

Lipp-Joao, K.H. and T.A. Brown. 1993. Enhanced transformation of tomato co-cultivated with Agrobacterium tumefaciens C58C1 Rif::Pgsfr1161 in the presence of acetosyringone. Plant Cell Rpt. 12:422-647.

Liu, R. and Z. Sanford. 1988. Plant regeneration by organogenesis from strawberry leaf and runner tissue. HortScience 23:1057-1059.

Mathews, H., W. Wagoner, J. Kellog, and R.K. Bestwick. 1995. Genetic transformation of strawberry: Stable integration of a gene to control biosynthesis of ethylene. In Vitro Cell Dev. Biol. 31:36-43.

Mathews, H. V.Dewey, W. Wagoner, and R.K. Bestwick. 1998. Molecular and cellular evidence of chimeric tissues in primary transgenics and elimination of chimerism through improved selection protocols. Transgenic Res. 7:123-129.

Mercado, J.A., I. Mansouri, S. Jiménez-Bermúdez, F. Pliego-Alfaro, and M.A. Quesada. 1999. A convenient protocol for extraction and purification of DNA from Fragaria. In Vitro Cell. Dev. Biol.-Plant 35:152-153.

Murashige, T. and F. Skoog. 1962. A revised medium for rapid growth and bioassays with tobacco tissue cultures. Physiol. Plant 15:473-497.

Nehra, N.S., R.N. Chibbar, K.K. Kartha, R.S.S. Datla, W.L. Crosby, and C. Stushnoff. 1990a. Genetic transformation of strawberry by Agrobacterium tumefaciens using a leaf disk regeneration system. Plant Cell Rpt. 9:293-298.

Nehra, N.S., R.N. Chibbar, K.K. Kartha, R.S.S. Datla, W.L. Crosby, and C. Stushnoff. 1990b. Agrobacterium-mediated transformation of strawberry calli and recovery of transgenic plants. Plant Cell Rpt. 9:10-13.

Nehra, N.S. and C. Stushnoff. 1989. Direct shoot regeneration from strawberry leaf disks. J. Amer. Hort. Sci. 114:1014-1018.

Nyman, M. and A. Wallin. 1992. Transient gene expression in strawberry (Fragaria $\times$ ananassa Duch.) protoplast and recovery of transgenic plants. Plant Cell Rpt. 11:105-108.

Ramallo, J.C., L.D. Ploper, M. Ontivero, M.P. Filippone, A. Castagnaro, and J. Díaz Ricci. 2000. First report of Colletotrichum acutatum on strawberry in northwestern Argentina. Plant Dis. 84:706.

Stomp, A. M. 1992. Histochemical localization of $\beta$ glucuronidase in GUS protocols: Using the GUS gene as a reporter of gene expression. Academic, New York.

Uratsu, S.L., H.Ahmadi, R.S. Bringhurst, and A.M. Dandekar. 1991. Relative virulence of Agrobacterium strain on strawberry. HortScience 26:196-199.

HortScience, Vol. 38(2), April 2003 